УДК 342.565

DOI https://doi.org/10.32844/2618-1258.2019.3-1.38

САВИЦЬКИЙ Я.Ф.

\title{
ЩОДО ПИТАННЯ ВИЗНАЧЕННЯ ПОНЯТТЯ АДМІНІСТРАТИВНО-ПРАВОВОГО СТАТУСУ АПЕЛЯЦЙНИХ ГОСПОДАРСЬКИХ СУДІВ В УКРАЇНІ
}

Стаття присвячена формулюванню визначення концепту «адміністративно-правовий статус апеляційних господарських судів в Україні». Визначено, що це сукупність загальних, спеціальних і специфічних складників, що характеризують апеляційний судовий орган господарської спеціалізації з об'єктивної та суб'єктивної сторін, розкриваючи при цьому його місце та значення в системі судових органів такого ж рівня 3 наданням можливості його виокремлення як окремої структурної одиниці з власним функціональним призначенням і соціальною метою. Визначено, що адміністративно-правовий статус апеляційних господарських судів в Україні $є$ потрійним: загальний - коло елементів, що $є$ спільними для всіх судових органів такого ж рівня; спеціальний - інстанційна спеціалізація аналізованих суб'єктів, що вирізняє їх від судових органів такого ж рівня; специфічний - сукупність закріплених адміністративною нормою засад та організаційно-функціональних правил діяльності апеляційного судового органу, що розкривається специфікою діяльності працівників його апарату й організаційно-структурною його побудовою зокрема. 3'ясовано, що в межах адміністративно-правового статусу апеляційних господарських судів в Україні доцільно виділяти об'єктивну та суб'єктивну його характеристики, різниця між якими полягає в деперсоніфікації як абстрактного суб'єкта, наділеного певними ознаками, чи, навпаки, у конкретизації суб'єкта, за яким закріплено коло правоможливостей. Відповідно, до об'єктивних характеристик належать загальні, спеціальні та частково специфічні структурні частини аналізованого адміністративно-правового статусу, а до суб'єктивних - специфічні, але тільки ті, що безпосередньо стосуються специфіки діяльності працівників апарату апеляційних господарських судів. Зроблено висновок, що адміністративно-правового статус апеляційних господарських судів в Україні - це сукупність загальних, спеціальних і специфічних складників, що характеризують апеляційний судовий орган господарської спеціалізації з об'єктивної та суб'єктивної сторін, розкриваючи при цьому його місце та значення в системі судових органів такого ж рівня з наданням можливості його виокремлення як окремої структурної одиниці з власним функціональним призначенням і соціальною метою.

Ключові слова: адміністративно-правовий статус, апеляційний господарський суд, апеляція, правове становище, правовий статус, статус, суд, судова влада.

The article devoted formulation of definition of "administrative and legal status of the appellate courts in Ukraine". It is determined that this is a set of common, special and specific components that characterize an appellate judicial body of economic specialization from an objective and subjective side, revealing its place and importance in the system of judicial bodies of the same level with the possibility of its separation as a separate structural unit with its own functional purpose and social purpose. It is determined that the administrative and legal status of commercial courts of appeal in Ukraine is threefold: general - a range of elements common to all judicial bodies of the same level; special - Instance specialization of the analyzed subjects, which distinguishes them from the judicial bodies of the same level; specific - a set of principles and organizational and functional rules of appeal of a court of appeal fixed by an administrative norm, which is revealed by the specific activity of the employees of its apparatus and its organizational and structural construction in particular. It is found out that within the administrative and legal status of economic courts of appeal in

(с) САВИЦЬКИЙ Я.Ф. - здобувач (Науково-дослідний інститут публічного права) 
Ukraine, to distinguish its objective and subjective characteristics, the difference between them is to depersonify as an abstract subject endowed with certain features or vice versa to specify the entity under which it is assigned, circle the right options. Accordingly, the objective characteristics include general, special and partially specifc structural parts of the analyzed administrative legal status, and subjective - specific, but only those that directly relate to the specific activity of employees of the Appellate Commercial Court apparatus. It is concluded that the administrative and legal status of economic courts of appeal in Ukraine is a set of general, special and specific components that characterize the judicial body of economic specialization from objective and subjective parties, while revealing its place and importance in the system of judicial bodies, of the same level with the possibility of its isolation as a separate structural unit with its own functional purpose and social purpose.

Key words: administrative and legal status, appeal, court, economic court, judicial authority, legal status, status.

Вступ. Входження України в європейський і світовий простір викликає потребу у відповідних перетвореннях у всіх сферах суспільного життя, адаптації основних державних інституцій до найкращих світових зразків. Насамперед це стосується саме судової системи, адже суд відіграє в житті будь-якої держави важливу роль, а в правовій країні правильно влаштований суд виконує нову важливу функцію - міцного гаранта прав громадянина, що проголошуються іiі конституцією. Сьогодні суд - це універсальний інститут, створений у державі для врегулювання конфліктних ситуацій [1, с. 45-46].

Актуальність розгляду адміністративно-правового статусу апеляційних господарських судів в Україні зумовлена першочергово динамічними змінами судоустрійного законодавства, упровадженням новітньої судової реформи, існуванням практичних прогалин у цій сфері, що мають наслідком неналежне забезпечення громадянам і господарюючим суб’єктам захисту їхніх прав і загалом відновлення соціальної та економічної справедливості.

3 теоретичного погляду аналіз концептуальних дефініцій, що становлять основу наукової думки стосовно адміністративно-правового статусу особи, в тому числі публічного органу, що реалізовує певний напрям державної політики, і виокремлення власного підходу до розуміння аналізованого явища закладають фундамент для подальших наукових пошуків у тому числі 3 метою виокремлення шляхів оптимізації діяльності апеляційних господарських судів в Україні.

Адміністративна наука має досить масштабний обсяг теоретичних напрацювань учених стосовно конструкції «адміністративно-правовий статус». Ця категорія розглядається вченими-адміністративістами з усіх боків і в різних сферах життєдіяльності суспільства. Зокрема, фундаментальний вклад для розвитку юридичної науки в цьому аспекті здійснили такі вчені, як В. Авер'янов, В. Бевзенко, Ю. Битяк, В. Галунько, Т. Коломоєць, Т. Кравцова, Р. Мельник і багато інших. Окремі аспекти адміністративно-правового статусу органів судової влади досліджували такі вчені, як М. Вишневський, А. Іванищук, Р. Ігонін, С. Ківалов, В. Кузьмишин, В. Куценко, С. Рудниченко, В. Салім, А. Тарнавська, О. Харитонова, М. Шатерніков та інші. Проте спеціалізовано представлена до розгляду нами тематика не була предметом наукових пошуків усіх вищезазначених дослідників.

Постановка завдання. Мета статті - сформулювати визначення концепту «адміністративно-правовий статус апеляційних господарських судів в Україні».

Результати дослідження. Адміністративно-правовий статус - це сукупний термін, який із-поміж власних специфічних особливостей наділений низкою ознак, що мають похідний характер. Тобто з метою визначення поняття адміністративно-правового статусу апеляційних господарських судів в Україні першочергово необхідно з'ясувати термінологічні та сутнісні характеристики категорій, від яких, власне, він походить.

Зокрема, поняття «статус» у Словнику іншомовних слів у перекладі з латинської означає «положення, стан кого-небудь чи чого-небудь» $[2$, с. $634 ; 3$, с. 19]. В усталеному розумінні статус - абстрактний багатозначний термін, у загальному змісті означає сукупність стабільних значень параметрів об'єкта або суб'єкта. Зі спрощеного погляду статус об'єкта або суб' єкта - це його стан або позиція, ранг у будь якій ієрархії, структурі, системі [4]. У науковій літературі надається таке енциклопедичне визначення: правове становище (сукупність прав та обов'язків) фізичної або юридичної особи [5, с. 626; 6; с. 326]. 
Щодо органів державного управління в Україні це поняття в системі нормативно-правових актів використовується досить широко. Наприклад, поняття «статус» використовується під час окреслення обов'язків, прав і повноважень як окремих органів державного управління, так і відповідних посадових осіб, щодо яких законами або нормативно-правовими актами такі обов' язки, права й повноваження визначаються [7, с. 82]. Щодо останніх свідчать праці В. Авер'янова, Н. Армаш, М. Бояринцева [8; 9; 10] та інших [6, с. 326].

Відповідно, аналізована категорія має щонайменше декілька змістових трактувань залежно від різновиду правовідносин, у яких він використовується. Більше того, вона $є$ історично сформованою та модернізованою під впливом зміни суспільно-політичних процесів у світі й нині наділена соціологічним чинником інтерпретування [11, с. 48].

Наприклад, поняття соціального статусу спочатку означало правове становище юридичної особи $[12$, с. 7]. У широкий науковий ужиток це поняття введено відомим німецьким соціологом Максом Вебером, який визначав статус, клас і владу як основні виміри соціальної стратифікації [13, с. 305, 927-937]. Відповідно, соціальний статус - соціальна позиція людини в межах групи або спільноти, яка пов'язана з ії певними правами й обов'язками. Саме за допомогою поняття «статус» ми ідентифікуємо один одного в різних соціальних структурах $[14$, с. $151 ; 15$, с. 335$]$.

Доволі часто в науковій літературі тотожними виявляються поняття «правовий статус» $\mathrm{i}$ «юридичний статус». Точніше, мова йде про використання в науковому слововжитку недиференційованого поняття «правовий статус»; саме цим поняттям позначають явище «юридичний статус». Останній регламентується тим обсягом можливостей і свободи, які суспільство й держава можуть реально гарантувати індивіду. Юридичний статус особи як поняття відображає лише те, що притаманне кожному громадянинові держави, залишаючи неврахованим усе приватне або групове. Юридичний статус особи - це сукупність прав, обов'язків, законних інтересів, гарантій їх реалізації, що закріплені в законодавстві й характеризують особу як суб'єкта права [16, с. 26].

Як бачимо, категорії «соціальний статус» і «юридичний статус» концептуально стосуються саме громадянина або особи в розумінні попереднього терміна.

Зазначаючи про правовий статус як категорію, що може стосуватися державних органів та апеляційних господарських судів зокрема, необхідно відмітити, що в юридичній енциклопедії це поняття трактується як «сукупність прав і обов'язків фізичних та юридичних осіб. В Україні визначається Конституцією, законами та іншими нормативно-правовими актами, міжнародними договорами, ратифікованими Верховною Радою України. Правовий статус фізичної особи визначають насамперед конституційні права, свободи та обов'язки людини і громадянина. Правовий статус юридичних осіб визначається через їх компетенцію, тобто права і обов'язки цих осіб, зафіксовані в чинному законодавстві... Від повноти юридичної фіксації повноважень даних юридичних осіб залежить ефективність їхньої діяльності» [17; 18, с. 108]. Відповідно, цей термін має двозначне трактування залежно від особи та місця, у якій ієрархічній системі вона знаходиться.

Деякі науковці відстоюють позицію про доцільність розмежування понять «правовий статус» $\mathrm{i}$ «правове становище». Так, М. Вітрук, відокремлюючи правове становище від правового статусу, характеризує становище як більш широке поняття, й наводить такі його елементи: правовий статус, громадянство, правосуб'єктність, юридичні гарантії. Він наполягає, що правове становище - це узагальнена категорія, що розкриває всі елементи закріпленого в праві стану особи, які перебувають між собою у визначених зв'язках і в соціальному плані зумовлені тим місцем, яке особа посідає в системі суспільних відносин [19, с. 10-11, 40]. На думку О. Харитонової, навпаки, правовий статус асоціюється зі стабільним правовим станом суб'єкта, а правове становище змінюється залежно від правовідносин, у яких він бере участь [20, с. 71; 21, с. 36]. Окремо варто зазначити про існування ще однісї окремої думки щодо аналізованої проблематики: категорія «правовий статус» стосується особи, тоді як «правове становище»- публічного органу влади [11, с. 50].

Проте, як зазначає А. Зубко, гра термінологією не впливає на загальну сутність розуміння. Тому правовий статус він визначає через сукупність юридично закріплених варіацій становища суб'єкта в державі та суспільстві, зумовлених комплексом прав та обов'язків. Швидше за все для уникання наукових обговорень і «термінологічної гри» законодавець переважно апелює категорією «статус» без уточнення галузевої належності. Ми долучаємося до думки тих науковців, які вважають, що в подібних випадках доцільніше застосувати категорію «адміністративно-правовий статус», який є різновидом попереднього з усіма властивими йому загальними ознаками й окремо наділений власною специфікою, зумовленою галузевою належністю [11, с. 49-50; 22$, c. 85$]$. 
До речі, правовий статус є ширшим за значенням від аналізованого. Конституційні засади, на яких базується правовий статус, впливають на встановлення принципів правового статусу в усіх галузях права, зокрема й адміністративного. Крім цього, на зміст адміністративно-правового статусу також впливають норми інших галузей права та норми міжнародного права [23, с. 195; 24, c. 57].

3 приводу поняття адміністративно-правового статусу особи, що зустрічаються в науковій літературі, можна виокремити два основні підходи. Першого дотримується більшість науковців. Він полягає в тому, що поняття адміністративно-правового статусу розкривається через характеристику його елементів. Інша частина науковців детально розглядає зміст адміністративно-правового статусу через компетенцію [25, с. 33].

Наприклад, адміністративно-правовий статус суб'єктів публічної адміністрації, які здійснюють публічне адміністрування транскордонного співробітництва України та країн-учасниць $€ \mathrm{C}, \mathrm{M}$. Рівіс трактує як правове становище різних за своєю природою публічних суб'єктів (органів місцевого самоврядування, місцевих органів виконавчої влади, представників Державної митної та державної прикордонної служб на пропускних пунктах), яке розкривається через сукупність юридичних засобів (завдань, повноваження, відповідальності) з метою досягнення такого стану, коли зовнішній кордон України з СС стане прозорим і безбар'єрним як у фізично-технічному, так і формально-правовому розуміннях [26, с. 93-94]. Досліджуючи адміністративно-правовий статус Державної судової адміністрації (далі - ДСА) України як суб'єкта забезпечення модернізації системи судової влади, С. Рудниченко визначає його як сукупність конституційних та адміністративних норм і принципів, що породжують існування юридичних засобів, за допомогою яких з'являється змога відокремити ДСА України від інших суб'єктів публічного адміністрування в цій сфері й з'ясувати його значення під час забезпечення модернізації системи судової влади шляхом надання їй усього потрібного для здійснення правосуддя суддями та надання якісних адміністративних послуг у системі судової влади [27, с. 51]. Адміністративно-правовий статус суб'єктів публічної адміністрації, що здійснюють адміністративно-правове регулювання діяльності апарату суду в Україні, на думку М. Вишневського, є теоретичною категорією, що розкриває особливості функціонування внутрішнього та зовнішнього рівнів публічної адміністрації в цій сфері, репрезентуючи при цьому особливості їх владно-розпорядчого, регулювального впливу на діяльність апарату суду в Україні за допомогою сукупності взаємопов'язаних і взаємозалежних елементів, що загалом розкриває їх значення та роль у процесі функціонування останнього [22, с. 87]. Зокрема, В. Куценко адміністративно-правовий статус ДАС визначає як цілісну, структуровану, загальну, універсальну категорію, що характеризує роль ДАС у здійсненні нею їі адміністративної діяльності на основі норм адміністративного права [24, с. 57].

Більш спеціалізовано до предмета дослідження доречним є наведення думки В. Саліма, який під адміністративно-правовим статусом господарського суду розуміє сукупність закріплених нормами адміністративного права кола повноважень, якими наділений господарський суд для виконання покладених на нього державою завдань, що реалізуються як під час господарського процесу, так і поза ним [28, с. 135-136]. Натомість М. Шатерніков адміністративно-правовий статус господарських судів розглядає як установлену в нормах адміністративного права сукупність ознак, що з урахуванням завдань, функцій і повноважень цих органів визначає їхнє правове становище серед інших суб'єктів адміністративно-правових відносин [29, с. 64].

Як бачимо, більшість зазначених науковців акцентує увагу, що адміністративно-правовий статус визначає правове становище суб'єкта в певній ієрархічній структурі. Фактично в їхньому розумінні домінує змістове означення категорії «статус» із доданням галузевого правового чинника - адміністративних норм, де й варто шукати відповідні елементи, що формують його зміст.

Доречно вказати, що окремі дослідники наголошують на тому, що не можна ототожнювати поняття адміністративно-правового статусу органу й адміністративно-правовий статус посадових осіб цих органів. Так, наприклад, А. Головін визначає адміністративно-правовий статус міліції громадської безпеки як урегульоване сукупністю норм адміністративного права ії̈ юридичне становище щодо реалізації компетенції апарату, служб і підрозділів з охорони правопорядку, забезпечення прав і свобод громадян і безпеки в суспільстві [30], а адміністративно-правовий статус працівника міліції громадської безпеки як зумовлену реальними суспільними відносинами сукупність спеціальних юридичних прав, обов'язків і законних інтересів працівників, пов'язану із завданнями й функціями повсякденної службової діяльності та їхнім соціальним призначенням [31;32, с. 33].

Однак указаний науковець, визначаючи аналізовані категорії, досліджував особливості діяльності органу виконавчої влади. У нашому випадку мова йде про апеляційний господарський 
суд, єдиний судовий орган в системі судової влади й унікальну особливу форму організації державної установи, яка виконує спеціалізовану суспільно необхідну функцію - реалізовує основоположне завдання держави щодо забезпечення громадян і суб'єктів господарської діяльності захистом, безпекою та є гарантом відновлення справедливості. На наш погляд, суд можна розглядати з багатьох позицій, однак у будь-якому разі основне його призначення реалізовує суддя. Невід'ємними його структурними елементом також $є$ апарат відповідного суду, зокрема його працівники. Тобто належне здійснення правосуддя передбачає злагоджену, хоча й відокремлену роботу працівників апеляційного судового органу господарської спеціалізації - суддів та організаційного персоналу, оскільки існувати окремо один від одного вони не можуть. Наявна чітка взаємозалежність, хоча й існує їх роздільність і функціональна незалежність. Зокрема, судді не можуть впливати на процеси діяльності апарату суду, так й останні - на суддів. Фактично увесь апарат працює на благо й задля реалізації посадових обов'язків суддів.

У зв'язку з цим є сенс стверджувати, що адміністративно-правовий статус апеляційних господарських судів в Україні є потрійним: 1) загальний - коло елементів, що є спільними для всіх судових органів такого ж рівня; 2) спеціальний - інстанційна спеціалізація аналізованих суб'єктів, що вирізняє їх від судових органів такого ж рівня; 3) специфічний - сукупність закріплених адміністративною нормою засад та організаційно-функціональних правил діяльності апеляційного судового органу, що розкривається специфікою діяльності працівників його апарату й організаційно-структурною його побудовою зокрема. При цьому останню структурну частину можна було уважати підвидом загальної, так як основні правила забезпечення суддівської діяльності є єдиними. Однак, на нашу думку, у зв'язку з тим що кожна апеляційна господарська установа на власний розсуд розпоряджається наданими їй ресурсами, має власні, відмінні від інших судових органів, запити для забезпечення судовою адміністрацією й загалом може мати доречну до своїх потреб штатну структуру та організаційну побудову, є сенс виокремити іiі у відносно самостійну частину.

Отже, ми пропонуємо в межах адміністративно-правового статусу апеляційних господарських судів в Україні виділяти об'єктивну й суб'єктивну його характеристики, різниця між якими полягає в деперсоніфікації як абстрактного суб'єкта, наділеного певними ознаками, чи, навпаки, у конкретизації суб'єкта, за яким закріплено коло правоможливостей. Відповідно, до об’єктивних характеристик належать загальні, спеціальні та частково специфічні структурні частини аналізованого адміністративно-правового статусу, а до суб'єктивних - специфічні, але тільки ті, що безпосередньо стосуються специфіки діяльності працівників апарату апеляційних господарських судів.

Висновки. Усе вищенаведене дає можливість резюмувати, що адміністративно-правовий статус апеляційних господарських судів в Україні - це сукупність загальних, спеціальних і специфічних складників, що характеризують апеляційний судовий орган господарської спеціалізації з об'єктивної та суб'єктивної сторін, розкриваючи при цьому його місце й значення в системі судових органів такого ж рівня з наданням можливості його виокремлення як окремої структурної одиниці з власним функціональним призначенням і соціальною метою.

\section{Список використаних джерел:}

1. Кузьмишин В. Судова реформа в Україні: які досягнення маємо на сьогодні та що потрібно для того, аби реформа була дієвою. Вісник Вищого адміністративного суду України. 2012. № 4. C. 45-49.

2. Мельничук О.С. Словник іншомовних слів. Київ, 1974. 826 с.

3. Макарчук В.В. Поняття «правовий статус особи» в теоретично-правовій літературі. Право.иа. 2015. № 3. С. 18-22.

4. Перекладаємо слово статус. Словотвір. 2017. URL: https://slovotvir.org.ua/words/status.

5. Шемшученко Ю.С. Юридична енциклопедія : у 6 т. Київ : Укр. енцикл., 2003. Т. 5 : П-С.

6. Харенко О.О. Адміністративно-правовий статус центрального органу виконавчої влади: проблема змісту. Актуальні проблеми держсави і права. 2011. Вип. 60. С. 325-330.

7. Гудима Н. Проблема статусу центральних органів виконавчої влади у реформуванні державного управління. Свропейські перспективи. 2010. № 4.

8. Бояринцев М. Адміністративно-правовий статус громадян: до питання про склад елементів. Право Украӥни. 2002. № 8.

9. Армаш Н. Особливості адміністративно-правового статусу керівників органів виконавчої влади, що обіймають посади державних політичних діячів. Право України. 2006. № 10. C. $71-74$. 
10. Авер'янов В.Б. Державне управління в Україні. Київ, 1999. 266 с.

11. Зубко А.О. Адміністративно-правовий статус Департаменту міжнародних спорів Міністерства юстиції України : дис. ... канд. юрид. наук : 12.00 .07 / Науково-дослідний інститут публічного права. Київ, 2019. 211 с.

12. Сапов В.В. Статус социальной теории. Современная западная социология : словарь. Москва : Политиздат, 1990. С. 331-332.

13. Weber M. Economy and Society. An Outline of Interpretive Sociology. Berkeley : Univ. of California Press, 1978. In 2 vol. 1470 p.

14. Социология : учебник / Ю.Г. Волков, В.И. Добреньков, В.Н. Нечипуренко, А.В. Попова. 2-е изд., испр. и доп. Москва : Гардарики, 2003. 512 с.

15. Горбачова Н.I. Соціальний статус і соціальна роль як базові поняття соціальної структури. Вісник Житомирського державного університету імені Івана Франка. 2013. Вип. 1. C. 234-237.

16. Тарнавська А.Н. До питання про юридичний статус особи. Адвокат. 2009. № 3. С. 26-29.

17. Шемшученко Ю.С. Юридична енциклопедія : у 6 т. Київ : Укр. енцикл., 1998.

18. Чумак О.О. Адміністративно-правовий статус державного виконавця. Публічне право. 2013. № 1. С. 107-113.

19. Витрук Н.В. Общая теория правового положения личности. Москва : Норма, 2008. 210 с.

20. Кивалов С.В. Административное право Украины : учебник. Харьков : Одиссей, 2004. 880 с.

21. Ківалов С.В., Харитонова О.І. Адміністративно-правові відносини (проблеми теорії) : монографія. Одеса : Юридична література, 2004. 324 с.

22. Вишневський М.В. Адміністративно-правове регулювання діяльності апарату суду в Україні : дис. ... канд. юрид. наук : 12.00.07 / Науково-дослідний інститут публічного права. Київ, 2019. 219 c.

23. Сердюк В.І. Адміністративно-правовий статус громадян України як різновид правового статусу. Міжнародно-правове забезпечення стабільності та безпеки суспільства : матеріали Науково-теоретичної конференції викладачів, аспірантів та студентів юридичного факту, м. Суми, 25 травня 2013 р. / ред. кол. : А.М. Куліш, М.М. Бурбика, та ін. Суми : СумДУ, 2013. C. $195-196$.

24. Куценко В.Д. Адміністративно-правовий статус Державної судової адміністрації України : дис. ... канд. юрид. наук : 12.00 .07 / НДІПП. Київ, 2016. 223 с.

25. Гумін О.М. Адміністративно-правовий статус особи: поняття та структура. Hame право. 2014. № 5. С. 32-37.

26. Рівіс М.М. Публічне адміністрування транскордонного співробітництва України та країн-учасниць ЄС : дис. ... канд. юрид. наук : 12.00.07 / Науково-дослідний інститут публічного права. Київ, 2018. 217 с.

27. Рудниченко С.М. Адміністративно-правове регулювання діяльності державної судової адміністрації України : дис. ... канд. юрид. наук : 12.00.07 / НДІПП. Київ, 2017. 226 с.

28. Салім В.В. Поняття і зміст адміністративно-правового статусу господарських судів. Вісник Чернівецького факультету Національного університету "Одеська юридична академія». 2017. Вип. 4. С. $128-137$.

29. Шатерніков М.І. Адміністративно-правовий статус господарських судів: сутність і зміст. Право і Безпека. 2016. № 2. С. 60-64.

30. Головін А.П. Адміністративно-правове регулювання діяльності міліції громадської безпеки : автореф. дис. ... канд. юрид. наук : 12.00.07 / Нац. акад. внутр. справ України. Київ, 2004. $20 \mathrm{c}$.

31. Санжарук Т.О. Правовий статус як властивість індивідуального суб'єкта права та компетенція як властивість колективного суб'єкта права. Актуальні проблеми держави і права. 2005. Вип. 25. С. 122-128.

32. Катрич Д.К. Адміністративно-правовий статус Національної поліції України: поняття і зміст. Науковий вісник Ужгородського національного університету. Серія «Право». 2016. Вип. 36 (2). С. $31-35$. 